Williams, R. E. O. (1954). J. gen. Microbiol. 10, 337-341

\title{
Glucuronidase Production by Serotypes of Streptococcus pyogenes
}

\author{
By R. E. O. WILLIAMS \\ Streptococcal Reference Laboratory, Public Health Laboratory Service, Colindale, \\ London, N.W. 9
}

SUMMARY: Seven hundred and thirty-six strains of Streptococcus pyogenes were examined for production of glucuronidase. The types most commonly found producing the enzyme were 9 and 28 . Among other types there appeared to be some inverse relation between production of glucuronidase and of the $\mathbf{M}$ antigen.

Two recent reports (Robinson, Blinn \& Frank, 1952; Jacox, 1953) have shown that the ability to produce glucuronidase varies among the different serological types of Streptococcus pyogenes (Lancefield's group A). In both studies the type identification of the streptococei was based exclusively on the $\mathbf{M}$ precipitin method of Swift, Wilson \& Lancefield (1943) and a large proportion of the strains (22 and $\mathbf{3 9} \%$ ) were untypable. Moreover, a substantial proportion of the untypable strains produced glucuronidase. In this laboratory, Griffith's (1934) slide-agglutination method of typing is used as well as Lancefield's precipitin method, and we are thus able to identify, to some extent, most of the strains that are untypable by the precipitin method (Williams \& Maxted, 1953). It therefore seemed worth investigating the glucuronidase production of a number of strains that had been typed by our routine.

\section{MATERIAL AND METHODS}

This report is based on a total of 736 strains isolated by constituent laboratories of the Public Health Laboratory Service, and by a number of laboratories in Northern Ireland, during 2 weeks, 17-23 November 1952 and 10-16 May 1953, in a survey carried out to determine the distribution of types then current in the country. The strains were isolated from patients and healthy carriers. All were shown to belong to group A.

Type identification was carried out here or in the Regional Laboratories of the Service at Cambridge, Cardiff and Oxford. All strains were tested by slide agglutination and subsequently by precipitation. Strains that were not agglutinated by any sera, and a few that gave very complex agglutination patterns were tested in the precipitin test against all the type sera available; otherwise the precipitin test was used to confirm or make more precise the type diagnosis based on the agglutination test.

Phenolphthalein glucuronide was prepared by my colleague Mr T. Nash from a sample of the cinchonidine base made by Mr B. W. L. Brooksbank (Barber, Brooksbank \& Kuper, 1951) and kindly given me by Dr Mary Barber. It was incorporated at a concentration of $0.0002 \mathrm{~m}$ in serum agar. The streptococci under test were grown overnight in $10 \%(\mathrm{v} / \mathrm{v})$ serum broth at $37^{\circ}$ and a loopful was spotted on to the surface of plates of the glucuronide agar. These 
were incubated overnight at $37^{\circ}$ and then exposed to ammonia, as in the method of Barber \& Kuper (1951). Strains were considered to have produced glucuronidase when a distinct pink colour developed around the colony. Preliminary tests with the strain of Str. pyogenes Blackmore (type 11) as used by Robinson $e t$ al. showed that under these conditions the glucuronide concentration used was optimum. With $0.5 \%(\mathrm{w} / \mathrm{v})$ glucose in the glucuronide agar none of twenty glucuronidase-producing strains produced any detectable breakdown of the glucuronide in this test (cf. Jacox, 1953).

\section{RESULTS}

In Table 1 are set out the types of the strains, determined both by agglutination and precipitation methods, and their glucuronidase production. The order is arranged to bring together those types, such as 3 and 13, which are known to share antigens. In some cases the agglutination test gave a complex pattern and, when the precipitin reaction was negative, the type could not be determined; it was, however, often possible to tell that the strain was probably related to one or more of the recognized types. Such strains are entered under headings such as 'Misc. 3, 13, B 3264'.

Of the 736 strains tested, seventy-nine $(\mathbf{1 0 . 7} \%)$ produced glucuronidase; this was only common among strains of two types, namely type 28 and type 9 , although eight of the ten strains that were agglutinated by the serum for type 12 but failed to give a precipitin reaction were also positive. It should be noted that of the types giving unclassifiable agglutination patterns, nine were agglutinated by sera for type 9 and also for type 18 or 30 , and of these seven produced glucuronidase; this may indicate that they should really be regarded as type 9 .

Of the 736 strains, $\mathbf{3 5 3}$ gave a reaction in the $M$ precipitin test [and thirtyseven precipitated with the serum for type 28 , in which the type-specific antigen is different from the typical $M$ antigen (Lancefield \& Perlman, 1952)]. Of these 353 strains $4.3 \%$ produced glucuronidase. This compares with $11.8 \%$ of the 346 strains that produced no demonstrable $M$ antigen, and $62.6 \%$ of the thirty-seven type 28 strains.

It has been our experience that anti-M sera for precipitin typing are very much easier to prepare and more satisfactory to use with some types than with others (Williams \& Maxted, 1953). The satisfactory types, of those represented in Table 1, are 1, 2, 3, 24, 29, 5, 12, 6, 14, 19,30 and 18. There was a total of 384 strains distributed over these twelve types, of which $324(85 \%)$ gave a precipitin reaction and sixty failed to precipitate. Only three $(0.9 \%)$ of the 324 precipitin-positive strains produced glucuronidase, compared with nine $(15.0 \%)$ of the sixty precipitin-negative strains (difference $=14 \cdot 1 \%$, standard error $=2 \cdot 4$ ).

For some other types, represented in the present series by 4, 9, 22 and 25 , we have found the preparation of satisfactory anti-M sera to be difficult, and with the sera available precipitin reactions are commonly negative $(86 \%$ in the present collection). Of the 202 strains of these types, $13.4 \%$ produced glucuronidase, but although none of the four strains of type 4 that produced 
Table 1. Glucuronidase production by serotypes of Streptococcus pyogenes

\begin{tabular}{|c|c|c|c|c|c|}
\hline \multirow[b]{3}{*}{ 'Type' } & \multirow{3}{*}{$\begin{array}{l}\text { Precipitin } \\
\text { test }\end{array}$} & Type reaction in & \multirow{3}{*}{$\begin{array}{l}\text { No. of } \\
\text { strains } \\
\text { tested }\end{array}$} & \multicolumn{2}{|c|}{$\begin{array}{l}\text { Strains } \\
\text { producing } \\
\text { glucuronidase }\end{array}$} \\
\hline & & & & & \\
\hline & & Agglutination test* & & No. & $\%$ \\
\hline \multirow[t]{2}{*}{1} & 1 & $1 ;-\dagger$ & 88 & $\mathbf{0}$ & \\
\hline & - & 1 & 4 & 1 & $(25 \cdot 0) \ddagger$ \\
\hline \multirow[t]{2}{*}{2} & 2 & 2 & 14 & 1 & $7 \cdot 1$ \\
\hline & - & 2 & 7 & 0 & \\
\hline \multirow[t]{2}{*}{3} & $\mathbf{3}$ & $3 \pm 13$, B 3264; - & 61 & 2 & $\mathbf{3} \cdot \mathbf{3}$ \\
\hline & - & 3 & 29 & 0 & \\
\hline \multirow[t]{2}{*}{13} & - & 13 & 9 & 3 & $(\mathbf{3 3 \cdot 3})$ \\
\hline & - & Misc. 3, 13, B 3264 & 19 & 1 & $\mathbf{5} \cdot \mathbf{3}$ \\
\hline \multirow[t]{2}{*}{4} & 4 & 4 & 14 & 0 & \\
\hline & - & 4 & 91 & 4 & $4 \cdot 4$ \\
\hline 24 & 24 & - & 3 & 0 & \\
\hline 29 & 29 & 4 & 2 & 0 & \\
\hline 28 & 28 & $28 \pm 4(11 / 27 / 44 \S)$ & 37 & $\mathbf{2 3}$ & $62 \cdot 2$ \\
\hline 5 & $\mathbf{5}$ & $5 \pm 11,12,27,44 ;-$ & 49 & 0 & \\
\hline 11 & - & 11 & 2 & 0 & \\
\hline \multirow[t]{3}{*}{12} & 12 & $12 \pm 5,11,27,44 ;-$ & 68 & 0 & \\
\hline & - & & 10 & 8 & $80 \cdot 0$ \\
\hline & - & $\begin{array}{r}\text { Misc. } 5,11,12,27,44 \text { including } \\
\text { some reacting also with } 3,13\end{array}$ & 53 & $\mathbf{5}$ & $\mathbf{9} \cdot \mathbf{4}$ \\
\hline \multirow[t]{2}{*}{6} & 6 & $6 ;-$ & 14 & $\mathbf{0}$ & \\
\hline & - & 6 & $\mathbf{3}$ & $\mathbf{0}$ & \\
\hline \multirow[t]{2}{*}{$8 / 25$} & 25 & $25 \pm 8$ & 4 & 2 & $(50 \cdot 0)$ \\
\hline & - & $25 ; 8 / 25 ;$ Imp. 19 & 23 & 4 & $17 \cdot 4$ \\
\hline \multirow[t]{2}{*}{9} & 9 & $9,9 / 18$ & 11 & 10 & $90 \cdot 9$ \\
\hline & - & 9 & 36 & $\mathbf{5}$ & $13 \cdot 9$ \\
\hline \multirow[t]{2}{*}{14} & 14 & 14 & 5 & 0 & \\
\hline & - & 14 & $\mathbf{3}$ & 0 & \\
\hline \multirow[t]{2}{*}{18} & 18 & $18 ; 9 / 18 ; 18 / 30 ;-$ & 6 & $\mathbf{0}$ & \\
\hline & - & 18 & 1 & $\mathbf{0}$ & \\
\hline 19 & 19 & $\pm 15,17,19,23,47 ;-$ & 12 & $\mathbf{0}$ & \\
\hline \multirow[t]{3}{*}{30} & 30 & $\pm 15,17,19,23,47 ;-$ & $\mathbf{2}$ & 0 & \\
\hline & - & 30 & 1 & 0 & \\
\hline & - & Misc. $18,22,23,30$ & 1 & $\mathbf{0}$ & \\
\hline 22 & - & 22 & 23 & 2 & $8 \cdot 7$ \\
\hline \multirow[t]{3}{*}{ Unclassifiable } & - & $9 / 18$ & 7 & 6 & $(85 \cdot 7)$ \\
\hline & - & $9 / 30$ & 2 & 1 & $(50 \cdot 0)$ \\
\hline & - & $\begin{array}{l}\text { 1/13/B 3264; } ; 4 / 22 ; 4 / 27 ; \\
14 / \operatorname{Imp.~} 19 ; 18 / 27 / 44\end{array}$ & 13 & 1 & $7 \cdot 7$ \\
\hline Negative & & & 9 & 0 & \\
\hline Total & & & 736 & 79 & $10 \cdot 7$ \\
\hline
\end{tabular}

* Under 'agglutination test' are given the type numbers of the sera that agglutinated the strains. The entry $3 \pm 13, \mathrm{~B} 3264$, etc., indicates that some of the strains were agglutinated by type 3 alone, some by 3 and 13, some by 3,13 and $B$ 3264 etc. Entries such as 9/18 indicate definite agglutination patterns.

$\dagger-=$ no reaction.

$\ddagger=$ percentages in parentheses are based on less than ten strains.

$\S=$ one strain. 
glucuronidase gave precipitation with the $\mathbf{M}$ antiserum, ten of the fifteen type 9 and two of the six type 25 strains did so.

Summarizing these results in a different way (Table 2), of the seventy-nine strains which hydrolysed the glucuronide, only $3 \cdot 8 \%$ gave $M$ precipitin reactions with sera known to be satisfactory, and $51.9 \%$ gave no precipitin reaction at all. No less than $29 \cdot 1 \%$ of the remainder were type 28 .

\section{Table 2. Typing reactions of 79 glucuronidase-producing strains of}

\section{Streptococcus pyogenes}

Typable by precipitation

with 'satisfactory' anti-M sera

with anti-M sera of doubtful value

with anti-R serum for type $\mathbf{2 8}$

Typable by agglutination only

in types usually giving good $\mathrm{M}$ precipitinogens

in types rarely giving good $M$ precipitinogens

in types for which no anti-M sera were available (11 and 13)

but giving only pattern reactions

Agglutination reactions complex and unclassifiable

\begin{tabular}{|c|c|c|}
\hline $\begin{array}{l}\text { No. of } \\
\text { strains }\end{array}$ & $\%$ of & total \\
\hline 3 & $3 \cdot 8$ & \\
\hline 12 & $15 \cdot 2\}$ & $48 \cdot 1$ \\
\hline 23 & $29 \cdot 1$ & \\
\hline 9 & $11 \cdot 4$ & \\
\hline 15 & $19 \cdot 0$ & \\
\hline 3 & $3.8\}$ & $51 \cdot 9$ \\
\hline 6 & $7 \cdot 6$ & \\
\hline 8 & $10 \cdot 1$ & \\
\hline 79 & $100 \cdot 0$ & \\
\hline
\end{tabular}

\section{DISCUSSION}

The results reported here in part confirm, but also extend, the earlier observations of Robinson et al. and of Jacox. The overall percentage of glucuronidaseproducing strains, $10 \cdot 7 \%$, lies between the $16 \cdot 1 \%$ reported by Jacox, and the $4.0 \%$ of Robinson et al.; the frequency of the enzyme production by type 28 also confirms Jacox's findings. Jacox reported that 'all the strains of types 11, 13,25 and 28 ... contained glucuronidase', but this was based on single strains of types 11, 13 and 25 . In the present series three of nine type 13, six of twenty-seven type $8 / 25$, but neither of two type 11 strains, were active. Type 9, which we found active, was not recognized as a glucuronidaseproducing strain by the previous workers, doubtless because of the difficulty of recognizing this type by the precipitin method. It is further of some interest that even among types readily recognized by the precipitin test, the strains which failed to give a precipitin reaction were significantly more often able to hydrolyse glucuronide than those which gave a typical precipitin reaction.

The previous workers observed that glucuronidase production was common among strains untypable by the $M$ precipitin method. From the present work it is clear that this derives partly from the ability of some types not recognizable by the precipitin test to produce glucuronidase. It is also partly due to an apparent inverse relation between ability to produce glucuronidase and $\mathbf{M}$ antigen demonstrable within particular types. Lastly, the only type in which glucuronidase production is really common and which is readily recognizable by the precipitin test is type 28 , and in this type the antigen recognized in the standard precipitin test differs from typical $\mathbf{M}$ antigens in several ways.

My thanks are due to Mr P. Jerram for technical assistance. 


\section{REFERENCES}

Barber, M., Brooksbank, B. W. L. \& Kuper, S. W. A. (1951). Staphylococcal phosphatase, glucuronidase and sulphatase. J. Path. Bact. 63, 57.

BARBER, M. \& KUPER, S. W. A. (1951). Identification of Staphylococcus pyogenes by the phosphatase reaction. J. Path. Bact. 63, 65.

Griffith, F. (1934). The serological classification of Streptococcus pyogenes. J. Hyg., Camb. 34, 542.

JACox, R. F. (1953). Streptococcal $\beta$-glucuronidase. J. Bact. 65, 700.

Lancefield, R. C. \& Perlman, G. E. (1952). Preparation and properties of a protein ( $R$ antigen) occurring in streptococci of group $A$, type 28 and in certain streptococci of other serological groups. J. exp. Med. 96, 83.

Robinson, J. J., Blinn, C. W. \& Frank, P. F. (1952). Glucuronidase production by Streptococcus pyogenes. J. Bact. 64, 719.

Swift, H. F., Wilson, A. T. \& LANCEField, R. C. (1943). Typing group A hemolytic streptococci by $M$ precipitin reactions in capillary pipettes. J. exp. Med. 78, 127 .

Williams, R. E. O. \& MAXTED, W. R. (1953). The type classification of Streptococcus pyogenes. Proc. 6 Congr. int. Microbiol., Rome (in the Press).

(Received 6 November 1953) 